Pontifícia Universidade $C_{\text {atólica }}$

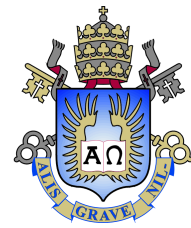

Felipe Chokin Tanaka Kotinda

\title{
Debt Collection in peer-to-peer lending market
}

\author{
Dissertação de Mestrado
}

Dissertation presented to the Programa de Pós-graduação em Economiada PUC-Rio in partial fulfillment of the requirements for the degree of Mestre em Economia.

Advisor: Prof. Juliano Assunção

Rio de Janeiro

July 2020 


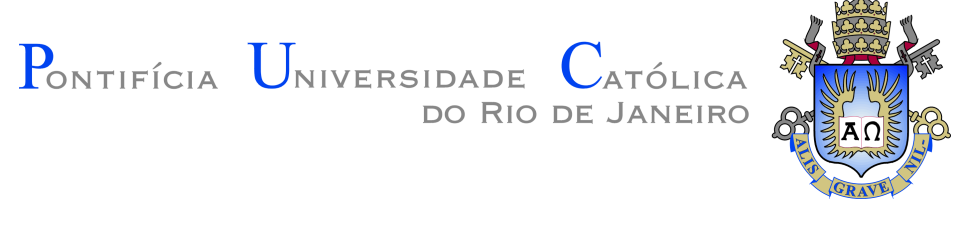

Felipe Chokin Tanaka Kotinda

Debt Collection in peer-to-peer lending market

Dissertation presented to the Programa de Pós-graduação em Economiada PUC-Rio in partial fulfillment of the requirements for the degree of Mestre em Economia. Approved by the Examination Committee.

Prof. Juliano Assunção

Advisor

Departamento de Economia - PUC-Rio

Prof. Gabriel de Abreu Madeira Departamento de Economia - FEA USP

Prof. Christiano Arrigoni Coelho IBMEC - RJ

Rio de Janeiro, July the 26th, 2020 
All rights reserved.

\section{Felipe Chokin Tanaka Kotinda}

B.A. in Economics, University of Sao Paulo (USP-SP), 2016.

Bibliographic data

Tanaka Kotinda, Felipe Chokin

Debt Collection in peer-to-peer lending market / Felipe Chokin Tanaka Kotinda; advisor: Juliano Assunção. - Rio de janeiro: PUC-Rio, Departamento de Economia, 2020.

v., 38 f: il. color. ; $30 \mathrm{~cm}$

Dissertação (mestrado) - Pontifícia Universidade Católica do Rio de Janeiro, Departamento de Economia.

Inclui bibliografia

1. Economia - Teses. 2. - Teses. 3. crédito pessoal; 4. empréstimo peer-to-peer;. 5. cobrança de dívida;. 6. intermediação financeira;. I. Assunção, Juliano. II. Pontifícia Universidade Católica do Rio de Janeiro. Departamento de Economia. III. Título. 


\section{Acknowledgments}

I wish to thank my advisor Prof. Juliano Assunção for his guidance and rich contribution to this research. I am also thankful to the examination committee: Prof. Gabriel de Abreu Madeira and Prof. Christiano Arrigoni Coelho for their time and insightful comments.

I am extremelly grateful for the love of family (Reinaldo, Márcia and Paula) and friends (Lucas, Luiz, Raffael, Rui and Yan). My master's would not have been the same without your support and company throughout the process.

Finally, this study was financed in part by the Coordenação de Aperfeiçoamento de Pessoal de Nível Superior - Brasil (CAPES) - Finance Code 001. Financial support from CNPq and PUC-Rio is gratefully acknowledged. 


\section{Abstract}

Tanaka Kotinda, Felipe Chokin; Assunção, Juliano (Advisor). Debt Collection in peer-to-peer lending market. Rio de Janeiro, 2020. 38p. Dissertação de mestrado - Departamento de Economia, Pontifícia Universidade Católica do Rio de Janeiro.

P2P Lending connects borrowers and lenders via an online platform, cutting out traditional banking intermediation. By bearing the risk of borrowers defaulting on their loans, investors rely on the debt collection process. This paper investigates whether state debt collection laws affect the ability of debt collectors to recover charged-off debts. Results show that stricter regulation are linked with lower recovery rates, which in turn leads to extension of credit to safer borrowers.

\section{Keywords}

consumer credit; peer-to-peer lending; debt collection; financial intermediation. 


\section{Resumo}

Tanaka Kotinda, Felipe Chokin; Assunção, Juliano. Cobrança de dívida no mercado de empréstimos peer-to-peer. Rio de Janeiro, 2020. 38p. Dissertação de Mestrado - Departamento de Economia, Pontifícia Universidade Católica do Rio de Janeiro.

Empréstimos P2P conecta tomadores de crédito a investidores por meio de plataformas online, eliminando a necessidade de um banco comercial como intermediário. Ao assumirem o risco de inadimplência dos tomadores, os investidores dependem do processo de cobrança de dívida. Esse estudo investiga se leis estaduais de cobrança de dívida afetam a capacidade dos cobradores de recuperar dívidas liquidadas. Resultados mostram que regulações maís rígidas estão associadas a taxas de recuperação menores, o que por sua vez leva a expansão de crédito para tomadores mais seguros.

\section{Palavras-chave}

crédito pessoal; empréstimo peer-to-peer; cobrança de dívida; intermediação financeira; 


\section{Table of contents}

$\begin{array}{lll}1 & \text { Introduction } & 10\end{array}$

2 Literature Review $\quad 13$

3 Industry Background $\quad 15$

$\begin{array}{lll}3.1 & \text { P2P Lending } & 15\end{array}$

$\begin{array}{ll}3.2 \text { Debt Collection } & 16\end{array}$

4 Data 20

$5 \quad$ Empirical Strategy $\quad 23$

5.1 Impact on Recovery Rates 24

5.2 Robustness tests 28

$\begin{array}{lll}5.3 & \text { Impact on borrower and loan characteristics } & 30\end{array}$

6 Conclusions 32 


\section{List of tables}

$\begin{array}{lll}\text { Table } 4.1 & \text { Summary statistics } & 21\end{array}$

Table 5.1 Summary statistics before and after the law 23

Table 5.2 Effect of debt collection restrictions on recovery rates (Common Treatment Effect)

Table 5.3 Effect of debt collection restrictions on recovery rates by FICO Score group (Common Treatment Effect)

Table 5.4 Effect of debt collection restrictions on recovery rates (Separate Treatment Effect)

Table 5.5 Sensitivity to alternative specifications, samples and placebo test

Table 5.6 Effect of debt collection restrictions on borrower risk (Common Treatment Effect)

Table 5.7 Effect of debt collection restrictions on borrower risk (Separate Treatment Effect)

Table A1 Effect of debt collection restrictions on recovery rates: Event Study Estimates 


\section{List of Abreviations}

BEA - Bureau of Economic Analysis

FDIC - Federal Deposit Insurance Corporation

FICO - Fair Isaac Corporation

FDCPA - Fair Debt Collection Practices Act

HB - House Bill

SB - Senate Bill 


\section{Introduction}

Internet-based peer-to-peer (P2P) lending has shown impressive growth rates since its birth in 2006. By cutting out traditional institutions as middleman, P2P lending can offer higher returns for lenders and lower interest rates for borrowers. From investor's perspective, however, this financial disintermediation comes at a price: they bear the entire credit risk. When borrowers default on unsecured debts, debt collectors service come into play. To prevent unfair practices against consumers, several states in the United States of America have tightened their debt collection laws in recent years. In this paper, we study the impact of these restrictions on P2P lending market. We show that LendingClub post-charge recoveries diminish in response to state law enactment. Moreover, LendingClub take on safer borrowers at lower interest rates.

Online alternative lending platforms have evolved from connecting individual borrowers with individual lenders to marketplaces featuring institutional investors and securitization. In 2018, LendingClub - the world's largest P2P lending platform - originated around $\$ 11$ billion in personal unsecured loans compared to the $\$ 138$ billion in personal unsecured loan outstanding for the entire United States market. ${ }^{1}$ P2P lending's appeal comes from consumers experience - uncomplicated application processes and quicker approvals - but mainly from lower fees. Keeping pace with the industry, regulation has also been constantly evolving to better accommodate this new channel of credit. A relevant concern is the regulatory arbitrage. P2P lenders could be doing the same activities as traditional financial institutions but under lighter regulation.

LendingClub Notes are not insured by the Federal Deposit Insurance Corporation (FDIC), so debt collectors minimize investor's losses. In December 2013, credit card charge-off rates for all commercial banks was $3.6 \%{ }^{2}$, while charge-off rates for LendingClub loans was $8 \%^{3}$. The right and means to collect is crucial for the provision of credit since creditors expected returns take these costs into account. The Fair Debt Collection Practices Act (FDCPA), a federal law, sets limitations on how debt collectors can operate. It was designed

\footnotetext{
${ }^{1}$ TransUnion's Q4 2018 Industry Insights Report

${ }^{2}$ https://www.federalreserve.gov/

${ }^{3} \mathrm{https}$ ://www.lendingclub.com/info/demand-and-credit-profile.action
} 
to prevent abusive, deceptive and unfair practices. States are allowed to go further and provide broader coverage than the FDCPA. In general, the state rules governing debt collection analysed in this paper were aimed at preventing collectors from pursuing the wrong consumer or deceiving consumers regarding statute of limitations. Agencies would be obliged to substantiate the debt with additional documentation and provide more transparent disclosure of consumer rights. We make use of LendingClub data to estimate a difference-in-difference model of the effects of these state-level restrictions.

We find that tightening of debt collection laws reduce post-charge off recoveries on average, but the effect is small. Because collection is more relevant to borrowers with higher probability of default, we estimate separate effects by consumer's credit score. Our regression analysis shows a larger effect on recoveries for high risk borrowers. Allowing for specific treatment across states, we observe significant negative effects for three of them. Our evidence is consistent with Fedaseyeu (2015), who show that stricter debt collection regulations lower recovery rates on delinquent credit card loans.

In addition to our main result on post-charge off recoveries, we study the consequences for borrower's composition and loan characteristics. Though regulation on debt collection are designed to protect consumers, it can lead to unintended consequences as the costs of better practices are passed on to creditors and borrowers. Operational costs is a relevant factor explaining interest margins in banking (Maudos, 2004) and banks effectively pass them on. Lower recoveries means higher expected loss for investors. As a result, these restrictions are likely to jeopardize credit access in the form of higher interest rates, especially for riskier borrowers (Zywicki, 2015). Similarly, Sandler and Romeo (2018) estimate the effect of recent debt collection state laws and find that such restrictions raised prices on credit card accounts.

Ex ante, better consumer protection should lead to an increase in demand. Examining all loans originated from 2013 to 2018, we show that these law changes increased lending to safer, high-income borrowers. From the supply side, ex ante, LendingClub can address higher expected losses by increasing interest rate or by reducing credit access to high risk borrowers. Ex post we find a negative effect, suggesting a shift to prime accounts.

Our work is related to previous studies on debt collection industry and its regulation (Fedaseyeu, 2015; Zywicki, 2015; Fonseca, 2017; Sandler and Romeo, 2018; Braga, 2019) and to the recent literature on the rise of $\mathrm{P} 2 \mathrm{P}$ lending (Serrano-Cinca et al., 2015; Emekter et al., 2015; Morse, 2015; Malekipirbazari and Aksakalli, 2015; Cornaggia et al., 2018; Kafer, 2018; Jagtiani and Lemieux, 2018). 
The main contribution of this paper is in better understanding debt enforcement in P2P lending market. Though we focus on debt collection, other works have examined different channels through which legislation may affect consumer defaults and access to credit. Barth et al. (1983) document how statewide restrictions on wage garnishment (when money is legally withheld from paycheck and sent to creditor) are related to personal loans market. Gropp et al. (1997) show that bankruptcy exemptions (what asset you get to keep during and after bankruptcy) redistribute credit toward borrowers with high assets and Pattison (2017) explores changes in states' bankruptcy exemptions, arguing that higher exemptions do provide valuable insurance to consumers, but the interest rate cost is large.

The rest of this paper is organized as follows. Section 2 presents the literature review; section 3 presents P2P lending and debt collection industries background; section 4 describes data; section 5 reports empirical results; section 6 concludes. 


\section{2}

\section{Literature Review}

This study adds to the recent $\mathrm{P} 2 \mathrm{P}$ lending literature. In his survey article, Kafer (2018) discuss P2P lending from a risk perspective, advocating that it is riskier than traditional banking. Factors supporting his view include replacement of traditional soft information, herding behavior from investors and platform default risk. One appealing characteristic of fintech lenders is the of use alternative data sources when screening borrowers. Jagtiani and Lemieux (2018) compares loans made by LendingClub and similar loans originated by banks. He finds that seven years into business the correlation between LendingClub grade and borrower's FICO score declined 45\%, supporting the view that nontraditional data has been used for screening analysis. Moreover, this alternative data has allowed consumers with fewer or inaccurate credit records to have access to credit.

Serrano-Cinca et al. (2015) investigate the factors explaining loan default highlighting that $\mathrm{P} 2 \mathrm{P}$ lenders bear the credit risk and suffer a information asymmetry problem, since they are not experts in dealing with risk. Using LendingClub's database, they find loan purpose, annual income, current housing situation, credit history and indebtedness to be significant factors. Making use of the same data, Emekter et al. (2015) evaluates loan performance and finds that credit grade, debt-to-income ratio, FICO score and revolving line utilization play an important role in loan defaults. They conclude that higher interest rates charged on the high-risk borrowers do not compensate the higher probability of loan default.

Also exploring the risks posed by the disintermediation of P2P lending, Malekipirbazari and Aksakalli (2015) proposes a machine learning model (random forest) for predicting borrower status. Results indicate their method outperforms both FICO credit scores and LendingClub assigned grades in identifying good borrowers though they point to the caveat of misclassifying some of the good borrowers as bad. In accordance with Emekter et al. (2015), they show that high risk borrowers are not worth the higher returns from a expected return approach.

This paper also contribute to the literature of debt collection. Fedaseyeu (2015) investigates state debt collection laws from 1999 to 2012, constructing 
an index of restrictions. He then estimates the impact of these laws on revolving credit. Results suggest the number of third-party debt collectors and recovery rates on delinquent debt decline following stricter regulation, leading to fewer openings of credit cards.

Zywicki (2015) theoretically discuss in his article the new regulation by the Consumer Financial Protection Bureau. According to Zywicki (2015), though stricter regulation of debt collection practices can benefit consumers in default and increase demand for credit, overly restrictive regulation could result in higher interest rates and less access to credit, especially higher-risk consumers. Previous studies provide empirical evidence of this prediction (Sandler and Romeo, 2018; Fonseca, 2017). Furthermore, it may also have the unintended consequence of providing incentives for creditors to escalate their efforts to more aggressive collection practices. Sandler and Romeo (2018) studied the effects of recent state laws regarding debt collection and documented both a decrease in credit card access and increase in prices. According to Fonseca (2017), that used auto loan and credit card data, "The decrease in access to credit is stronger for borrowers with low credit scores, but is felt across the credit spectrum." I add to this literature by showing how these state regulations on debt collection can effectively impact loans originated through the growing P2P lending industry. 


\section{3 \\ Industry Background}

\section{1}

\section{P2P Lending}

$\mathrm{P} 2 \mathrm{P}$ lending is a form of marketplace lending that connects individuals looking to borrow directly with individuals interested in lending. Despite the absence of a financial institution as intermediary, an online platform mediates the loan process, charging a fee for the service. The process is as follows: borrowers apply for the loan; eligible borrowers according to the platform's criteria are approved; loans are posted on the P2P marketplace to be funded by investors, who have access to borrower's hard information. Since it relies entirely on online payments to complete the transaction, these platforms promise low interest rates for borrowers while keeping attractive returns to investors.

The world's largest P2P lending platform, LendingClub, has evolved a lot since it was founded in 2006. Back then, loans were funded by multiple investors (crowdfunding). By 2013, the platform began to bundle thousands of small loans into securities, offering them to institutional investors. This shift to securitization fostered much of the industry growth from 2013 onward.

The remarkable difference between $\mathrm{P} 2 \mathrm{P}$ lending and traditional banking lending is risk-bearing. While commercial banks are required to protect depositors and ultimately held accountable for non performing accounts, P2P platforms mediate the process without carrying the credit risk. If the borrower falls behind on his payments, private investors take the loss.

Our research focuses on one segment of P2P lending industry, unsecured consumer loans, to assess the impact of debt collection restrictions. Lending$\mathrm{Club}^{4}$ has made their data publicly available, reporting detailed information on each loan application approved since its foundation. Figure 3.1 displays the timeline of a LendingClub unsecured loan, from past due to in collection. We are specially interested in the collection activity that follows charge-off, from day 121 forward. Unfortunately, our data does not distinguish proceeds from sale to debt buyers and recoveries obtained from third-party collectors.

\footnotetext{
${ }^{4}$ https://www.lendingclub.com/
} 
Figure 3.1: LendingClub Debt Delinquency Timeline

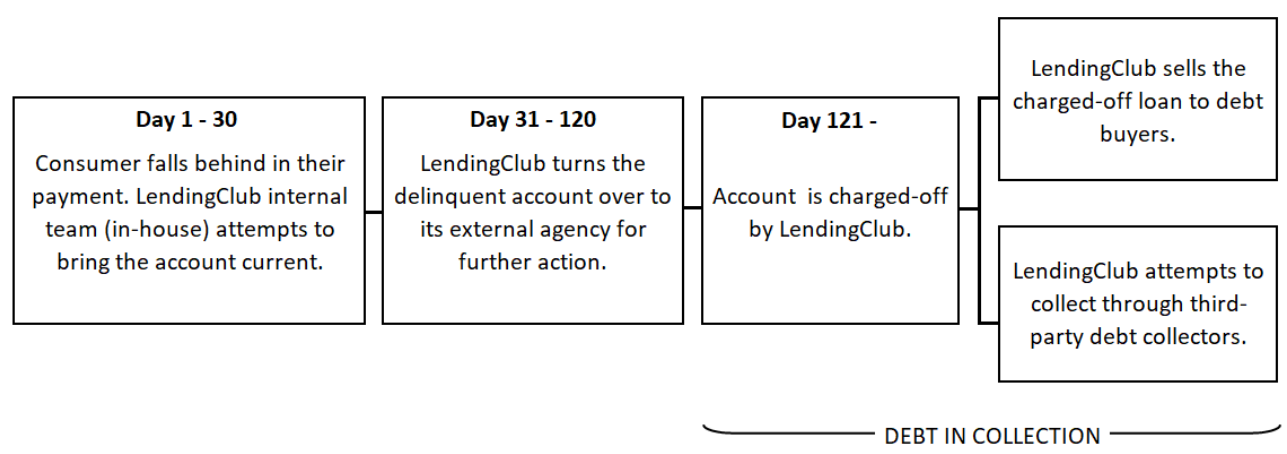

\section{2}

\section{Debt Collection}

Creditors expect consumers to pay their debt accordingly. However, when debtors fall behind payments, creditors rely on debt collection activity in an attempt to claim what is owed. Voluntary payment depends on the effectiveness of this system. Third-party debt collection activity in the United States is regulated by the Fair Debt Collection Practices Act of 1977 (FDCPA), which is administered by the Federal Trade Commission (FTC). The FDCPA was designed to prohibit practices considered unfair or abusive towards consumers, such as contacting repeatedly by phone or threatening legal action when it is not even plausible. However, it applies only to third-party debt collectors, not to the original creditor (in-house). Congress believes that creditors are already restrained by the incentive to protect their good will with customers. In contrast, when a creditor is attempting to collect a debt under another name, this independent debt collector is not concerned with future business or ongoing relationship. The federal act establishes a floor on consumer protection and allows states to impose further regulation, provided the protection is greater than what the federal law imposes.

California introduced the Fair Debt Buyers Practices Act (CA Debt Buyer Law) in January 2014. New York State enacted the NY Debt Collection Practices in December 2014. Colorado state amended its Colorado Fair Debt Collection Practices Act (CFDCPA) through a senate bill in August 2017. Oregon legislature passed a new regulation on debt buyers activity at the beginning of October 2017. The reforms we study generally require collectors to gather sufficient documentation to support their activity. This should help ensure that collection efforts target the correct consumers, avoid litigation if the statute of limitations has expired or if the debt has already been paid.

Restrictions were especially aimed at extending regulation to debt buyers 
- person or entity that has bought charged-off consumer debt - with the exception of New York, that already had debt buyer under the definition of debt collector. Prior to these changes, legislation was shady. Properly defining debt buyers is crucial because a debt that is repeatedly sold and resold without reliable documentation evidencing the original creditor often leads to collection against the wrong person.

In January 2014, California approved Senate Bill 233. The bill aims to regulate the activity of entities that purchase charged-off consumer debt by placing a long list of requirements related to account information for initial contact with debtor. Documentation must be sufficient to link the alleged debtor to the original contract. Debt buyers are prohibited from "making any written statement in an attempt to collect a consumer debt unless the debt buyer possesses information that the debt buyer is the sole owner or is authorized to assert the rights of all owners of the specific debt at issue, the debt balance, as specified, and the name and address of the creditor at the time the debt was charged off, among other things. ${ }^{n}$ They should also use specific disclosure language in collection communications, stating consumer's right regarding time-barred debt when it is beyond reporting or legal statute of limitation.

In Colorado, Senate Bill $216^{6}$ defines that debt buyers are collection agencies for purposes of the CFDCPA and as such are subjected to licensing and other requirements applied to debt collectors, in short, what is expected of a collection agency that purchases, sells, or attempts to collect on a purchased debt. It also creates new requirements for legal actions filed by debt collectors or collection agencies on debts owned by debt buyers. A debt collector or collection agency in Colorado, when bringing a legal action is required to provide evidence of each assignment of the debt establishing a chain of ownership starting with the creditor itself. Finally, it clarifies that the statute of limitations for private actions in the state is two years.

Oregon also passed legislation regulating debt buyers. House Bill 23567 was enacted in July 2017, and unlike other states, classifies debt buyers as a separate entity from debt collectors, with specific license requirement. Prior to that, debt buyers would not be held accountable for suing alleged debtors without providing basic information or even ensuring the debt is actually owned by the individual. Among other things, the law details the practices a debt buyer is required to follow to legally collect debt, specifies the type of notice to be provided to the debtor, duties of licensees and identifies more

\footnotetext{
${ }^{5}$ https://legiscan.com/CA/bill/SB233/2013

${ }^{6}$ https://legiscan.com/CO/bill/SB216/2017

${ }^{7}$ https://gov.oregonlive.com/bill/2017/HB2356/
} 
clearly unlawful collection practices. Upon consumer's request, documents substantiating the debt must be provided within 30 days and collection activity ceased until the right is proved. Moreover, the bill makes it a violation to file lawsuit on a debt that is past the statute of limitations, which in Oregon is two years.

In New York, when a debt collector first contacts an alleged debtor, new regulation demands the disclosure to include specific notices that were not formally required by the FDCPA. Collectors must prove they have the right to collect on the debt, through "a statement describing the complete chain of title from the original creditor to the present creditor, including the date of each assignment, sale, and transfer". ${ }^{8}$ Debt collectors usually do not retain evidence of past settlement agreements, so this requirement adds a cost burden. A history of the debt prevent other creditors from trying to collect the same debt. The new regulation also require disclosures regarding the collection of debts for which the statute of limitations has already expired. If a debt collector "knows or has reason to know" that the statute of limitations for a debt may have expired, the debt collector must provide a "clear and conspicuous" notification to the consumer that 1) the debt collector believes that the statute of limitations may be expired; 2) suing on a debt for which the statute of limitations has expired is a violation of the FDCPA, and, if the consumer is sued, the consumer may present evidence to the court that the statute of limitations has run; 3) the consumer is not required to provide the debt collector with an admission of any kind that the debt is still owed, or to waive the statute of limitations; and 4) a partial payment of the debt, or other admission that the debt is owed, may restart the statute of limitations.

Though these restrictions vary from state to state, they all build upon the federal protection. Considering the analyzed period, we exclude debt collection law changes that took place in Illinois, North Dakota and Maine. In January 2016, Senate Bill 1369 ammended Illinois Collection Agency Act. Its purpose was to reverse provisions and remove confusion from a previous year legislative enactment (August 2015) that conflicted with the FDCPA. Among others, the bill removed: the requirement that debt collectors provide the name and address of the original creditor in the initial consumer communication; and the requirement that debt collectors automatically identify their employer when communicating with individuals for the purpose of acquiring location information about a debtor. It also indicated that collection agencies would not be subject to civil liability for failure to comply with the requirements during the time when they were law. As such, we consider this law change as

\footnotetext{
${ }^{8}$ https://www.dfs.ny.gov/docs/legal/regulations/adoptions/dfsf23t.pdf
} 
not binding for collection activity.

North Dakota announced in June 2015 an increase to the annual licensing fee, as well as imposing other provision related to collection agencies better describing the process of changing names or addresses of a licensee. Maine adopted a new debt collection law in June 2017, adding new requirements for debt buyers. Both states are excluded from the analysis due to lack of data. 


\section{Data}

We use two sources of publicly data in this paper: 1) loan-level data of loans originated from LendingClub's website and 2) state macroeconomic variables from Bureau of Economic Analysis ${ }^{9}$, to account for possible omitted effects on outcome variables.

LendingClub platform covers the majority of the peer-to-peer lending market for unsecured personal loans in the United States. $\$ 53$ billions were issued as of September 2019. About $68.3 \%$ of borrowers report using their loans to refinance existing loans or pay off their credit cards. ${ }^{10}$ The full dataset contains a monthly pseudo-panel for each account with microlevel information on borrower's characteristics, contract terms and loan status. A Borrower's characteristics are income (monthly), state of residence, homeownership, employment length, number of inquiries in the last 6 months and FICO score at the time of application. For contract terms we have loan amount, interest rate and maturity (3 or 5 years). Finally, for loan status we have either fully paid or default, as well as information on post-charge off recoveries.

Our sample ranges from January 2013 to December 2018, and contain $2,164,766$ loans. It starts at 2013 because prior to that the number of observations was small, so inference would be less reliable. It ends at 2018 to allow collection efforts yield recoveries over at least a 6 -months post charge-off period. This 6 years time span seems reasonable to observe the impact of state laws. Panel A of Table 4.1 displays summary statistics of full sample. The average (median) borrower has a monthly income of $\$ 6,565(\$ 5,424)$ and a FICO Score of 698 (690). Lending Club assigns a grade to each loan, taking into account not only credit score, but also a combination of several indicators of credit risk from the credit report and loan application. Grades range from A (stronger credit profile) to $\mathrm{G}$ (weaker). Around $8 \%$ of loans were assigned a grade E, F or G, and we refer to them as "High Risk". Homeowners account for $61 \%$ of the consumers. The average employment length is 5.81 years, and around 0.56 inquiries were made in the 6 months prior to loan origination by the average borrower. As for contract characteristics, average yearly interest

\footnotetext{
${ }^{9}$ https://www.bea.gov/

${ }^{10}$ Loan purpose describes the reported intent of borrowers and may not reflect actual usage.
} 
rates in our sample is $13.1 \%$. Loan term is 36 months for about $70.9 \%$ of the accounts. Loan amount ranges from $\$ 1,000$ to $\$ 35,000$ with the mean at $\$ 15,163$. Average installment is $\$ 448$.

Table 4.1: Summary statistics

\begin{tabular}{lccccc} 
& Mean & P5 & P50 & P95 & SD \\
\hline Panel A: Full sample $(\mathrm{N}=2,164,766)$ & & & & & \\
\hline Monthly Income (US\$ thousands) & 6.57 & 2.33 & 5.42 & 13.67 & 9.54 \\
FICO Score & 698.24 & 660.00 & 690.00 & 765.00 & 32.90 \\
High Risk (grade $<\mathrm{D})$ & 0.08 & 0.00 & 0.00 & 1.00 & 0.28 \\
Homeowner & 0.61 & 0.00 & 1.00 & 1.00 & 0.49 \\
Employment length & 5.81 & 0.00 & 6.00 & 10.00 & 3.79 \\
Inquiries (last 6 months) & 0.56 & 0.00 & 0.00 & 2.00 & 0.86 \\
Interest Rate & 0.13 & 0.06 & 0.13 & 0.22 & 0.05 \\
Term & 42.98 & 36.00 & 36.00 & 60.00 & 10.90 \\
Loan Amount & 15,163 & 3,475 & 13,000 & 35,000 & 9,226 \\
Installment & 448.81 & 112.92 & 380.68 & 989.14 & 268.09 \\
& & & & & \\
\hline
\end{tabular}

\begin{tabular}{lccccc}
\hline Panel B: Charged-off Loans $(\mathrm{N}=184,909)$ & & & & \\
\hline Recovery Rate (\%) & 16.52 & 2.83 & 13.82 & 48.01 & 12.85 \\
Monthly Income (US\$ thousands) & 5.97 & 2.25 & 5.08 & 12.25 & 5.24 \\
FICO Score & 686.50 & 660.00 & 680.00 & 735.00 & 24.88 \\
High Risk (grade $<\mathrm{D})$ & 0.22 & 0.00 & 0.00 & 1.00 & 0.41 \\
Homeowner & 0.54 & 0.00 & 1.00 & 1.00 & 0.50 \\
Employment length & 5.61 & 0.00 & 6.00 & 10.00 & 3.81 \\
Inquiries (last 6 months) & 0.80 & 0.00 & 0.00 & 3.00 & 1.03 \\
Interest Rate & 0.16 & 0.08 & 0.15 & 0.25 & 0.05 \\
Term & 45.45 & 36.00 & 36.00 & 60.00 & 11.73 \\
Principal balance & 11,386 & 1,806 & 9,731 & 27,212 & 7,774 \\
Installment & 473.01 & 135.92 & 411.95 & 997.15 & 264.20 \\
& & & & & \\
\hline Panel C: Macro controls (state level) & 0.050 & 0.033 & 0.048 & 0.073 & 0.012 \\
Unemployment Rate & 0.009 & -0.004 & 0.009 & 0.021 & 0.008 \\
Personal Income Growth & & & &
\end{tabular}

Descriptive statistics for the main variables used in the empirical analysis.

Panel B reports summary statistics for the sub-sample of accounts in collection. 184,909 accounts were sent to collection, with about $30.6 \%$ of these during the last year (2018). The average recovery rate - defined as the ratio of post charged-off recoveries to remaining principal balance - is $17 \%$ ranging from $3 \%$ (5th percentile) to $48 \%$ ( 95 th percentile). Compared to the full sample, this sub-sample mean monthly income is lower, at $\$ 5.973$. FICO Score is around 686.50 , and $78 \%$ of accounts are assigned a grade A, B, C of D. About $54 \%$ are homeowner and employment length is 5.61 years. The average borrower has 0.8 inquiries in the last 6 months, with the 95 th percentile being 3 as opposed to 2 in Panel A. Interest rate is 3 percentage points higher than the full sample, and average principal balance at the time of default is $\$ 11,386$, with installment around $\$ 473$.

Lastly, Panel C provides information on state macro factors to control 
for general economic conditions. These may change contemporaneously with changes in state-level debt collection laws. During the period of 2013-2018, average monthly state unemployment was $5 \%$, and quarterly personal income growth $0.9 \%$. 


\section{Empirical Strategy}

Debt collection laws that make the activity of collection more costly, both by restricting practices and demanding licensing should reduce the recoveries obtained by LendingClub. Effectively, consumers under a more pro-consumer regulation should be less likely to repay their defaulted debt. Because the consumers ability to meet their obligations affect LendingClub willingness to lend, we also expect changes in debt contract characteristics: borrower's FICO score and income should increase, while interest rates decrease following the the legislation change.

Our identification strategy exploits time variation of the four state laws regarding debt collection. Fedaseyeu (2015) studied 29 changes in state regulations from 2000 to 2012, both changes that loosened and tightened the activity. We focus on instances in which the law was made more restrictive. Empirically, we test our predictions with the underlying assumption that these changes in legislation effectively impact the p2p lending industry.

Firstly, we conduct a uni-variate analysis by ignoring the time-series information and simply averaging the data 12 months before and 12 months after each of the four laws. As Table 5.1 with the aggregate summary statistics of the main variables illustrates, recovery rate declines and consumer riskiness change. Following the law, recovery rate dropped from $14.6 \%$ to $13.5 \%$.

Table 5.1: Summary statistics before and after the law

\begin{tabular}{lcccccccc} 
& \multicolumn{3}{c}{ Before } & & \multicolumn{3}{c}{ After } & \\
\cline { 2 - 4 } & Mean & P50 & SD & & Mean & P50 & SD & Dif p-value \\
\hline Recovery Rate (\%) & 14.61 & 13.93 & 12.83 & & 13.54 & 13.64 & 12.90 & 0,00 \\
Monthly Income & 6.41 & 5.42 & 0.02 & & 6.65 & 5.58 & 0.02 & 0.00 \\
FICO score & 695.07 & 690 & 0.13 & & 695.78 & 690 & 0.11 & 0,00 \\
High Risk (<D) & 0.101 & 0 & 0.00 & & 0.098 & 0 & 0 & 0.03 \\
Debt to Income & 18,86 & 16.16 & 183.24 & & 19.56 & 16.63 & 164 & 0.44 \\
Homeowner & 0.47 & 0 & 0.50 & & 0.45 & 0 & 0.50 & 0.00 \\
Employm. Length & 5.76 & 6 & 3.73 & & 5.68 & 6 & 3.81 & 0.00 \\
Interest Rate & 0.14 & 0.13 & 0.05 & & 0.13 & 0.13 & 0.05 & 0.00 \\
Term & 42.28 & 36 & 11 & & 42.99 & 36 & 11 & 0.00 \\
Loan amount & 14,584 & 12,500 & 8,548 & & 15,070 & 13,000 & 8,853 & 0.00 \\
Installment & 439 & 384 & 256 & & 441 & 379 & 261 & 0.21 \\
\hline
\end{tabular}

Descriptive statistics for the main variables used in the empirical analysis. Average in taken for 12 months before and 12 months after the law enactment. 
The average FICO score increased from 695.07 to 695.78. Likewise, the share of High Risk borrowers fell from $10.1 \%$ to $9.8 \%$. For loan characteristics, interest rates drop from $14 \%$ to $13 \%$. This indicates that LendingClub may be extending loans to safer borrowers at a lower interest rate in response to declining recoveries. Now we move to a multivariate regression analysis.

\section{1}

\section{Impact on Recovery Rates}

Our fixed effects difference-in-difference model for the effect of implementing a debt collection law on outcome $Y_{i s t}$ is as follows:

$$
Y_{i s t}=\alpha+\beta \text { Law }_{s t}+\lambda^{\prime} \text { Controls }_{i s t}+\mu_{s}+\gamma_{t}+f_{s}(t)+\epsilon_{i s t},
$$

where $i$ indexes borrowers, $s$ states and $t$ time, with $L a w_{s t}$ an indicator equal one if a debt collection took place in state $s$ and time $t$, Controls a vector of contract and borrower characteristics, $\mu_{s}$ and $\gamma_{t}$ are state and time fixed effects respectively and $f_{s}(t)$ is a state-specific time trend. The state and time fixed effects contain the indicators for treated and control states, pre-law and post-law periods. Following Bertrand et al. (2004), standard errors are clustered by state to account for arbitrary correlation between observations within the same state. $\beta$ is the difference-in-differences estimator of interest, which measures the effect of the law. In a difference-in-differences research design, the identifying assumption is of parallel trends. Conditional on controls and had the change in legislation not been enacted, outcome variables from states that did introduced changes in debt collection activity would have developed similarly to states that did not changed legislation.

We start by presenting results on recovery rate. They are shown in Table 5.2. We define recovery rate as post-charge recoveries divided by the remaining principal balance at the time of the default. Column 2 add state-specific linear time trend to address for possible differences in trends between the treated and control states. As expected, we can see from both specifications that increasing the restrictiveness of debt collection legislation result in lower recovery rates, though the coefficients are statistically insignificant. In column $1, \beta_{1}$ suggests that the recovery rate of an average defaulted loan is $0.4 \%$ lower after the law. If we scale our result with the FICO score coefficient, our point estimates is equivalent to a consumer's FICO score 72 points lower.

Debt collection restrictions are relevant to creditors only when borrowers fail to meet their loan obligations. We then expect to find different results for consumers of different risk profile. In column 3 of Table 5.2 we add an 
Table 5.2: Effect of debt collection restrictions on recovery rates (Common Treatment Effect)

\begin{tabular}{lccc}
\hline Dependent variable & \multicolumn{3}{c}{ Recovery Rate $(\%)$} \\
\cline { 2 - 4 } Law & $(1)$ & $(2)$ & $(3)$ \\
\cline { 2 - 4 } & -0.421 & -0.321 & $-0.273^{* *}$ \\
FICO Score & $(0.400)$ & $(0.314)$ & $(0.143)$ \\
& $0.006^{* * *}$ & $0.006^{* * *}$ & $0.007^{* * *}$ \\
Law*FICO Score & $(0.001)$ & $(0.001)$ & $(0.002)$ \\
& & & $0.004^{* *}$ \\
Borrower characteristics & & & $(0.002)$ \\
Loan characteristics & yes & yes & yes \\
Macro controls & yes & yes & yes \\
State Fixed effects & yes & yes & yes \\
Month Fixed effects & yes & yes & yes \\
Time trend & yes & yes & yes \\
Observations & no & yes & yes \\
R-squared & 184,909 & 184,909 & 184,909 \\
\hline
\end{tabular}

This table reports results from regressing recovery rate on law. All regressions include an intercept. Regressions controls are: borrower characteristics (monthly income, homeonwership, employment length and inquiries in the last 6 months), loan characteristics (interest rate and term), macro variables (state unemployment and state personal income growth), state fixed effects and month fixed effects. Robust standard errors in parentheses clustered at the state level. Month fixed effects are based on the month when the loan was charged-off. $* * * \mathrm{p}<0.01, * * \mathrm{p}<0.05, * \mathrm{p}<0.1$

interation term between Law and FICO Score. The positive coeffient suggests that lower recoveries are expected from borrowers of low credit profile. Figure A1 in Appendix displays the FICO score histogram for the sample of chargedoff loans, considering all states. In Table 5.3 we split the sample and re-estimate the specification with time trend separately for consumers with FICO score below 670 (first quartile) and those over 700 (fourth quartile).

There are 65,684 borrowers in the first group and 36,575 in the latter. As the second column show, treatment effect is higher for the lower FICO score group where we estimate a reduction in recovery rate of $1.05 \%$, significant at the 5\% level. Consistent with theoretical prediction from Zywicki (2015), higher-risk consumer are more susceptible to these law changes. These borrowers often have unstable income, making them less willing to meet their payments. In contrast, for high FICO score borrowers $(>700)$ we observe a small and statistically insignificant coefficient $\beta_{1}=0.665$.

In addition to the difference-in-differences estimates, we also conduct an event study to analyze the dynamics around the time of the law passage, testing the persistence of our estimated effect. There is substantial noise in monthly data, so for this approach we aggregate loans by quarter. We use the same equation (5-1) except for the variable Law that is replaced by eight quarter dummies, four quarters before and four after new legislation is effective. All four state laws have data available for the full event window, while Colorado and Oregon overlap within a two-month period. 
Table 5.3: Effect of debt collection restrictions on recovery rates by FICO Score group (Common Treatment Effect)

\begin{tabular}{|c|c|c|c|}
\hline \multirow[t]{3}{*}{ Dependent variable } & \multicolumn{3}{|c|}{ Recovery Rate (\%) } \\
\hline & (1) & $(2)$ & $(3)$ \\
\hline & All & $<670$ & $>700$ \\
\hline \multirow[t]{2}{*}{ Law } & -0.321 & $-1.046^{* *}$ & 0.665 \\
\hline & $(0.314)$ & $(0.479)$ & $(0.397)$ \\
\hline \multirow[t]{2}{*}{ FICO Score } & $0.005^{* * *}$ & -0.019 & $-0.011^{* * *}$ \\
\hline & $(0.001)$ & $(0.012)$ & $(0.002)$ \\
\hline Borrower characteristics & yes & yes & yes \\
\hline Loan characteristics & yes & yes & yes \\
\hline Macro controls & yes & yes & yes \\
\hline State Fixed effects & yes & yes & yes \\
\hline Month Fixed effects & yes & yes & yes \\
\hline Time trend & yes & yes & yes \\
\hline Observations & 184,909 & 65,684 & 38,575 \\
\hline R-squared & 0.044 & 0.039 & 0.063 \\
\hline
\end{tabular}

This table reports results from regressing recovery rate on law. All regressions include an intercept. Regressions controls are: borrower characteristics (monthly income, homeonwership, employment length and inquiries in the last 6 months), loan characteristics (interest rate and term), macro variables (state unemployment and state personal income growth), state fixed effects and month fixed effects. Column (1) shows the estimates for the entire sample of borrowers; column (2) and (3) for the subsamples of first and fourth quartile of FICO Score, respectively. Robust standard errors in parentheses clustered at the state level. Month fixed effects are based on the month when the loan was charged-off. $* * * \mathrm{p}<0.01, * * \mathrm{p}<0.05, *$ $\mathrm{p}<0.1$

We estimate:

$$
Y_{i s t}=\sum_{\tau=-4}^{4} \beta^{\tau} D_{s t}^{\tau}+\lambda^{\prime} \text { Controls } s_{i s t}+\mu_{s}+\gamma_{t}+f_{s}(t)+\epsilon_{i s t}
$$

where $D_{s t}^{\tau}$ are indicator variables that measures the time relative to the enactment quarter of the treated state. It is equal to one if a debt collection law was implemented $\tau$ quarters ago in state $s$ and quarter $t$. For control states, these indicator are zero in all periods. The omitted quarter is $\tau=0$. Therefore, each estimate of $\beta^{\tau}$ represents the recovery rate change in treated states relative to control states during quarter $\tau$, as measured from the quarter of law adoption. Results may be found in Appendix (Table A1).

We plot $\beta^{d}$ coefficients from equation (5-2) in Figure A6 with the $95 \%$ confidence intervals and observe a discrete drop in the quarters that follow the enactment. Recovery rates decreases by 0.42 percentage points in the first quarter, 1.07 in the second and 0.92 in the third. For quarter 4 the estimate returns to zero, which likely reflects LendingClub adapting to the new regulation. Despite the low power from only four treatments and accounting for the heterogeneity between them, Figure A6 is fairly consistent with the small coefficients presented in Table 5.2.

Up to now we have been treating the four debt collection restrictions as a homogeneous treatment, so results on Table 5.3 may mask law heterogene- 
Figure 5.1: Event Study of the effect of Debt Collection Restrictions on Recovery Rate

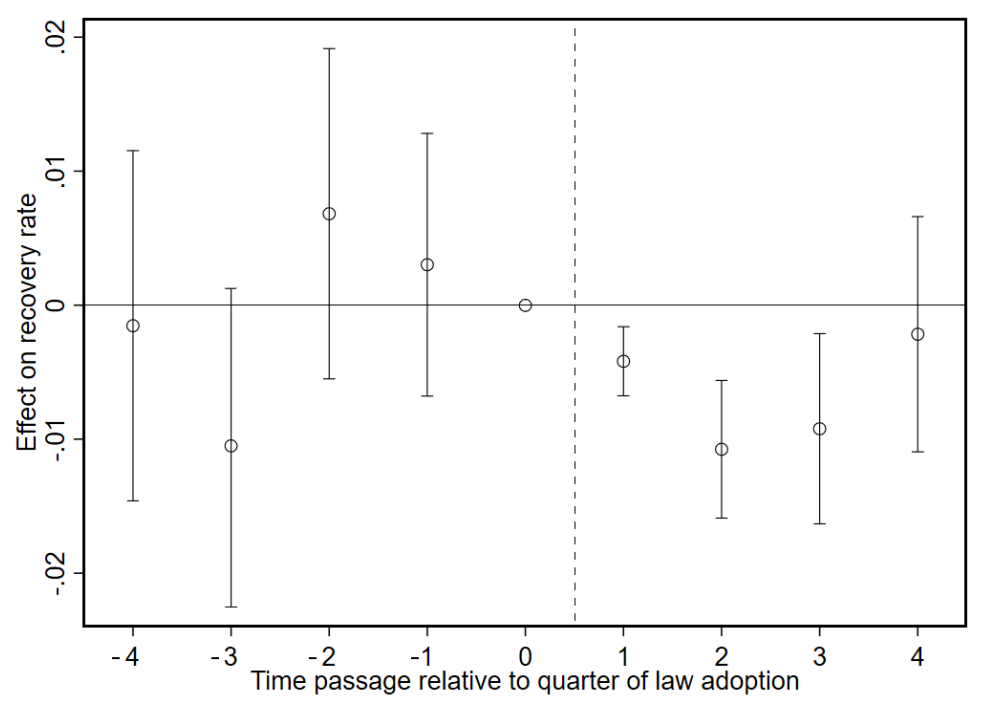

This figure report coefficients from the estimation of equation (5-2). The coefficients represent the change in recovery rate for treated states relative to control states in the four quarters before and four quarters after law is effective. See Appendix for regression results.

ity. As described earlier, state-level legislation will impose pre-requirements to prevent wrongful debt collection, clear disclosure of information when communicating with debtor and prescribe penalties if violation is found. Though they all seem to add protection to consumer, we expect them to affect the debt collection industry in different ways. In Table 5.4 we allow for separate treatment indicator for each of the four laws, also comparing the first and fourth quartiles of FICO Score. Figure A2 in Appendix displays FICO score histogram by state. The results are broadly similar and consistent with the common treatment effect estimated in Table 5.3. Recovery rates would be expected, ex ante, to raise in treatment states. For Colorado, New York and Oregon state law's we find negative effects on recovery rates. Further analysis on the quartiles of FICO reveals that this effect seem to be mainly driven by low score borrowers, as in the common treatment effect case. In these states, new legislation brought less recoveries to LendingClub. Conversely, California legislation seems to have positively impacted recoveries. In both subsamples of FICO scores recovery rate increased following the enactment of state law. We note that this difference may reflect the importance of this state for LendingClub. Around $14.4 \%$ or loans were originated in California, against the average $1.7 \%$ of the remaining states. We argue that LendingClub may be responding differently in its main market.

Finally, graphical evidence on the parallel trends assumption is presented in Figures A.3 to A.6 (Appendix). They plot the evolution of recovery rate on 
Table 5.4: Effect of debt collection restrictions on recovery rates (Separate Treatment Effect)

\begin{tabular}{lccc}
\hline Dependent variable & \multicolumn{3}{c}{ Recovery Rate $(\%)$} \\
\cline { 2 - 4 } & $(1)$ & $(2)$ & $(3)$ \\
CA Fair Debt Buyers Practices Act & All & $<670$ & $>700$ \\
\cline { 2 - 4 } & $1.295^{* * *}$ & $1.482^{* *}$ & $1.666^{* * *}$ \\
CO Fair Debt Collection Act & $(0.446)$ & $(0.558)$ & $(0.509)$ \\
& $-0.973^{* * *}$ & $-1.744^{* * *}$ & -0.403 \\
NY Debt Collection Regulation & $(0.181)$ & $(0.201)$ & $(0.314)$ \\
& $-0.883^{* * *}$ & $-1.636^{* * *}$ & 0.168 \\
OR Unlawful Debt Collection Practices & $(0.178)$ & $(0.223)$ & $(0.215)$ \\
& $-0.757^{* * *}$ & $-0.751^{* * *}$ & $-2.798^{* * *}$ \\
FICO Score & $(0.106)$ & $(0.101)$ & $(0.186)$ \\
& $0.005^{* * *}$ & $-0.0203^{*}$ & $-0.0130^{* * *}$ \\
Borrower characteristics & $(0.001)$ & $(0.012)$ & $(0.002)$ \\
Loan characteristics & yes & yes & yes \\
Macro controls & yes & yes & yes \\
State Fixed effects & yes & yes & yes \\
Month Fixed effects & yes & yes & yes \\
Observations & yes & yes & yes \\
R-squared & 184,909 & 65,684 & 47,673 \\
\hline
\end{tabular}

This table reports results from regressing recovery rate on each of the four laws. All regressions include an intercept, macro variables (state unemployment and state personal income growth), state fixed effects and month fixed effects. Column (1) shows the estimates for the entire sample of borrowers; column (2) and (3) for the subsamples of first and fourth quartile of FICO Score, respectively. Robust standard errors in parentheses clustered at the state level. Month fixed effects are based on the month when the loan was charged-off. ${ }^{* * *} \mathrm{p}<0.01,{ }^{* *} \mathrm{p}<0.05,{ }^{*} \mathrm{p}<0.1$

charged-off loans around each state law change. To be included in the control group, a state must not have missing data for the months in which these changes occurred.

\section{2 \\ Robustness tests}

This section reports results of some robustness tests. Table 5.5 displays the sensitivity of the effect of debt collection laws to alternative specifications and samples, as well as a placebo test. Each row in presents the results from the regression of recovery rate on the variable Law, set of controls (borrower and loan characteristics), state and month fixed effects. For each regression, only the Law coefficient and the corresponding standard error are reported. Row (1) reports estimates from baseline regressions of Table 5.3. In row (2) we exclude state-specific linear time trends in the specification. The effect of debt collection laws on recovery rates is similar to baseline and it seems to hold across the credit spectrum.

Row (3) test the sensitivity of the results to excluding months in which debt collection laws took place. There can be ambiguity on whether the month of enactment should be assigned one or zero. As seen in Table 5.5, estimates 
Table 5.5: Sensitivity to alternative specifications, samples and placebo test

\begin{tabular}{lccc}
\hline Dependent variable & \multicolumn{3}{c}{ Recovery Rate (\%) } \\
\cline { 2 - 4 } Specification & $(1)$ & $<670$ & $>700$ \\
\hline \multirow{2}{*}{ (1) Baseline specification } & All & $-1.046^{* *}$ & 0.665 \\
& & $(0.479)$ & $(0.397)$ \\
(2) Exclusion state x time trends & -0.321 & $-0.998^{*}$ & 0.267 \\
& $(0.314)$ & $(0.511)$ & $(0.433)$ \\
(3) Exclusion months in which laws changed & -0.421 & $-1.084^{* *}$ & 0.709 \\
& $(0.399)$ & $(0.494)$ & $(0.513)$ \\
(4) $1 \%$ trimming & -0.318 & $-1.137^{* * *}$ & 0.257 \\
& $(0.315)$ & $(0.364)$ & $(0.293)$ \\
(5) 5\% trimming & -0.519 & $-1.158^{* *}$ & 0.240 \\
& $(0.320)$ & $(0.494)$ & $(0.609)$ \\
(6) Placebo law changes & -0.862 & -0.038 & 0.122 \\
& $(0.662)$ & $(0.917)$ & $(0.167)$ \\
(7) Placebo law changes & 0.326 & -0.690 & -0.652 \\
& $(0.560)$ & $(0.444)$ & $(0.408)$ \\
(8) Placebo law changes & -0.314 & 0.166 & -0.514 \\
& $(0.292)$ & $(0.277)$ & $(0.758)$ \\
(9) Placebo law changes & 0.296 & 0.105 \\
(10) Placebo law changes & $(0.310)$ & $(0.234)$ & $(0.481)$ \\
& 0.937 & $-0.556^{*}$ \\
& $(1.399)$ & -0.488 & $(0.300)$ \\
\hline
\end{tabular}

This table reports results from variations on the baseline specification regressing recovery rate on law. Regressions are estimated at monthly frequency. Column (1) shows the estimates for the full sample of loans; column (2) and (3) for the subsamples of first and fourth quartile of FICO Score, respectively. The number of observations in each specification row for the full sample is as follows: (1) 184,909; (2) 184,909; (3) 184,545; (4) 181,244; (5) 166,689; (6) 184,909; (7) 184,909. Robust standard errors in parentheses clustered at the state level. Month fixed effects are based on the month when the loan was charged-off. $* * * \mathrm{p}<0.01$, ${ }^{* *} \mathrm{p}<0.05,{ }^{*} \mathrm{p}<0.1$

are comparable to baseline specification. Row (4) and (5) use trimmed samples of $1 \%$ and $5 \%$, respectively. Once again, results are similar.

Finally, rows (6-10) estimates the effect of placebo changes in debt collection laws on recovery rate. We construct the placebos by matching each state that effectively changed the law during the 2013-2018 period with a bordering control state that did not. From the possible states, we pick the one with recovery rate levels in the pre-law period most similar to the treated state. ${ }^{11}$ We then assume that the change in debt collection law occurred in the control state rather than in the treated. Since control states did not change their debt collection laws, we should expect no effect on recovery rate. As seen in bottom rows of Table 5.5, the impact of placebo law changes in the

\footnotetext{
${ }^{11}$ Matches obtained are (treated state - control state): row (6) California - Arizona, Colorado - Utah, New York - New Jersey, and Oregon - Nevada; row (7) California - Nevada, Colorado - Arizona, New York - Pennsylvania, and Oregon - Idaho; row (8) California Washington, Colorado - Kansas, New York - Massachusetts, and Oregon - Montana; row (9) California - North Dakota, Colorado - Nebraska, New York - New Hempshire, and Oregon Idaho; row (10) California - South Dakota, Colorado - Oklahoma, New York - Pennsylvania, and Oregon - New Mexico.
} 
first quartile of FICO score are insignificant.

\section{3}

\section{Impact on borrower and loan characteristics}

Our result in the previous subsection suggest restrictions on debt collection law reduce LendingClub recoveries on the grounds that collection efforts becomes more difficult and expensive. Thus, it should lead to a decrease in the supply of credit since creditors will be less willing to lend. However, a decrease in recoveries can also lead to an increase in the demand for credit through a moral hazard channel. Consumers will be willing to take on more debt. The magnitude of these responses will determine the net effect on access to credit.

We report results using the full sample. In Table 5.6 we re-estimate equation 5-1 with loan amount, monthly income and interest rate as dependent variables. In the first column we define the natural log of loan amount. The Law coefficient is positive, suggesting a loan $0.8 \%$ larger. The second column presents the semilog specification for monthly income, and we find that the average consumer income is higher in the post-law period. Lastly, we observe the estimated effect that the law had on interest rate. The coefficient is small $\left(\beta_{1}=-0.001\right)$, though significant.

Table 5.6: Effect of debt collection restrictions on borrower risk (Common Treatment Effect)

\begin{tabular}{lccc}
\hline Dependent variable & $\ln ($ Loan Amount $)$ & $\ln ($ Monthly Income $)$ & Interest Rate \\
\cline { 2 - 4 } Law & $0.00830^{*}$ & $0.01066^{* *}$ & $-0.00108^{* * *}$ \\
& $(0.0048)$ & $(0.0041)$ & $(0.0003)$ \\
Macro controls & yes & yes & yes \\
State FE & yes & yes & yes \\
Month FE & yes & yes & yes \\
Time trend & yes & yes & yes \\
Observations & $2,164,766$ & $2,164,035$ & $2,164,766$ \\
R-squared & 0.01 & 0.02 & 0.02 \\
\hline
\end{tabular}

This table reports results from regressing $\ln ($ Loan Amount), $\ln$ (Monthly Income) and interest rate on each of the four laws. All regressions include an intercept, macro variables (state unemployment and state personal income growth), state fixed effects, month fixed effects and a linear time trend. Robust standard errors in parentheses clustered at the state level. Month fixed effects are based on the month when the loan was originated. $* * * \mathrm{p}<0.01, * * \mathrm{p}<0.05, * \mathrm{p}<0.1$

As with recovery rates, the effect could be different across states. We proceed with a separate treatment effect regression (Table 5.7). The estimated treatment effect on loan amount is positive for Colorado, New York and Oregon, varying from an increase of $1.3 \%$ in Oregon to $3 \%$ in Colorado. In California we observe a small and insignificant effect. The second column presents the semilog specification for monthly income, and we find in all four 
states a positive impact. And for interest rates, the four state coefficients are small and negative, significants with the exception of California $\left(\beta_{1}=-0.0003\right)$. For instance, in Colorado the estimate suggests a $0.2 \%$ decrease in interest rates following the enactment of state law. These effects are robusts to the inclusion of control variables related to borrowers loan characteristics.

Table 5.7: Effect of debt collection restrictions on borrower risk (Separate Treatment Effect)

\begin{tabular}{lccc}
\hline Dependent variable & $\ln ($ Loan Amount) & $\ln ($ Monthly Income) & Interest Rate \\
\cline { 2 - 4 } CA FDBPA & -0.00017 & $0.00783^{* * *}$ & -0.00033 \\
& $(0.0036)$ & $(0.0021)$ & $(0.0003)$ \\
CO FDCA & $0.03357^{* * *}$ & $0.03631^{* * *}$ & $-0.00248^{* * *}$ \\
& $(0.0084)$ & $(0.0051)$ & $(0.0003)$ \\
NY DCR & $0.01628^{*}$ & 0.00449 & $-0.00160^{* * *}$ \\
& $(0.0089)$ & $(0.0030)$ & $(0.0002)$ \\
OR UDCP & $0.01316^{* *}$ & 0.00539 & $-0.00201^{* * *}$ \\
& $(0.0053)$ & $(0.0033)$ & $(0.0003)$ \\
Macro controls & yes & yes & yes \\
State FE & yes & yes & yes \\
Month FE & yes & yes & yes \\
Time trend & yes & yes & yes \\
Observations & $2,164,766$ & $2,164,035$ & $2,164,766$ \\
R-squared & 0.01 & 0.02 & 0.02 \\
\hline
\end{tabular}

This table reports results from regressing $\ln$ (Loan Amount), $\ln$ (Monthly Income) and interest rate on each of the four laws. All regressions include an intercept, macro variables (state unemployment and state personal income growth), state fixed effects, month fixed effects and a linear time trend. Robust standard errors in parentheses clustered at the state level. Month fixed effects are based on the month when the loan was originated. *** $\mathrm{p}<0.01, * * \mathrm{p}<0.05,{ }^{*} \mathrm{p}<0.1$

Altogether, these estimates suggest some heterogeneity between states and especially in California, consistent with results in Table 5.4. As mentioned earlier, it is possible that this is due to the sample of California being much larger than other states. LendingClub would be expected, ex ante, to deny credit to low score borrowers so as to offset lower recovery rates. In Colorado, New York and Oregon this seems to be the case, as we observe an increase in loan amount and a decrease in interest rates. Meanwhile, in California LendingClub's most important state - these effects are not observed. Ex post, there could be a concern on losing market share. In summary, we argue our findings on credit access suggest that in Colorado, New York and Oregon the decrease in supply resulting from stricter collection laws dominates the increase in demand. We find no evidence of similar effect in California. 


\section{6 \\ Conclusions}

In this paper we examine the impact of four state debt collection laws on P2P lending market. These restrictions extended legislation to cover debt buyers, required collectors to obtain additional documentation to substantiate the debts as well as provided better standards for what constitutes unfair or deceptive acts or practices. With the exception of California, our evidence suggest that these laws resulted in lower post-charge off recoveries from LendingClub, and that the decrease is stronger for borrowers with low credit scores. Moreover, these requirements reduced access to credit as borrowers in the post-law period are on average of higher income, with larger and cheaper loans.

Though the purpose of stricter regulation of debt collection is to benefit consumers who are in default, overly restrictive regulation can bring about unintended consequences to the very subprime borrowers they were trying to protect. While we make use of data from a single P2P lending firm, our results should be general enough to apply to other fintech firms originating unsecured personal loans. 


\section{Appendix}

Figure A1: FICO score histogram - United States

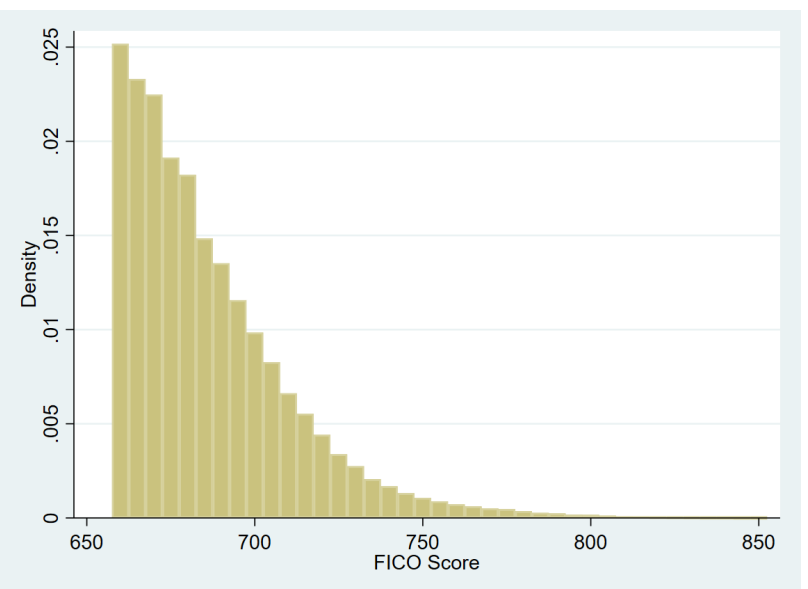

Figure A2: FICO score histogram - by state
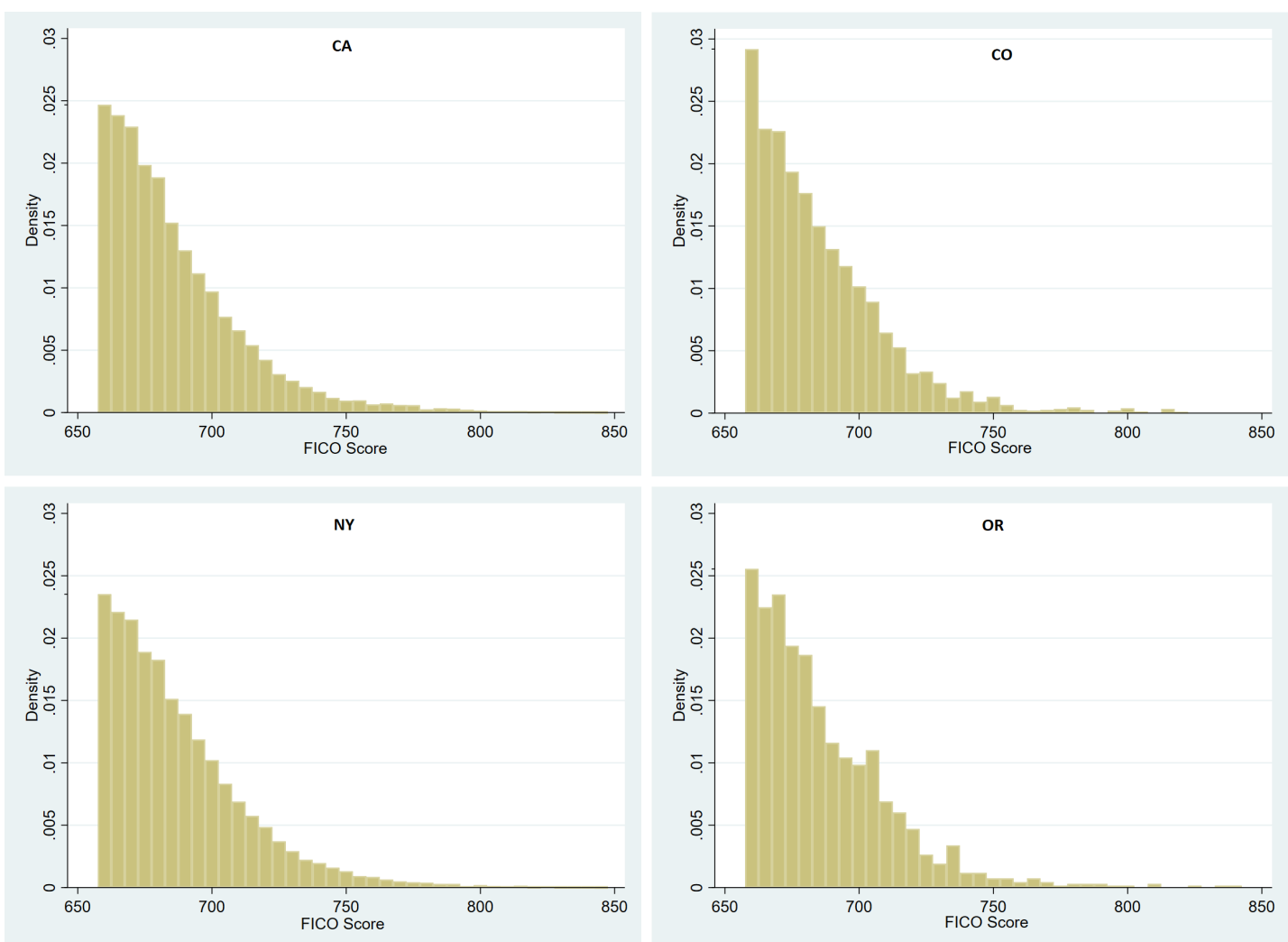
Figure A3: Average recovery rate for California and control states

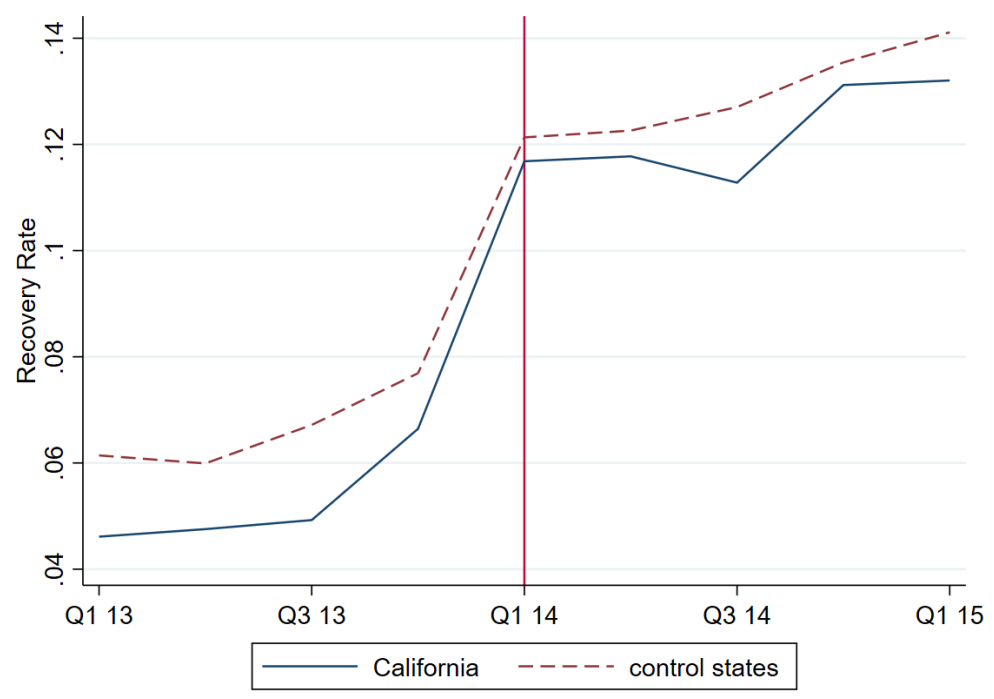

Figure A4: Average recovery rate for Colorado and control states

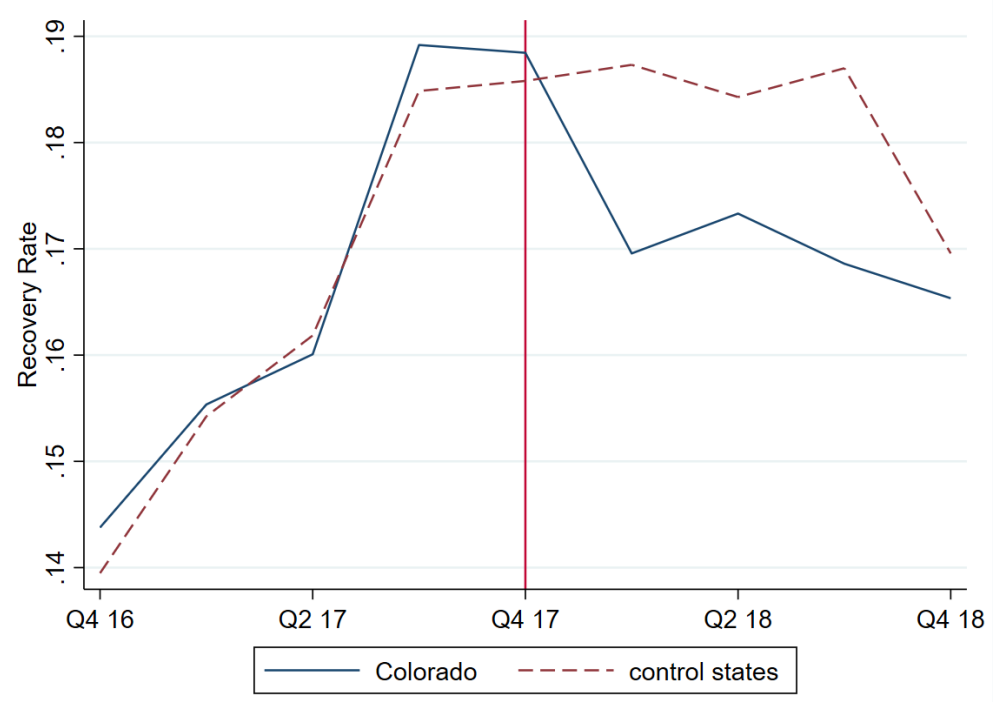


Figure A5: Average recovery rate for New York and control states

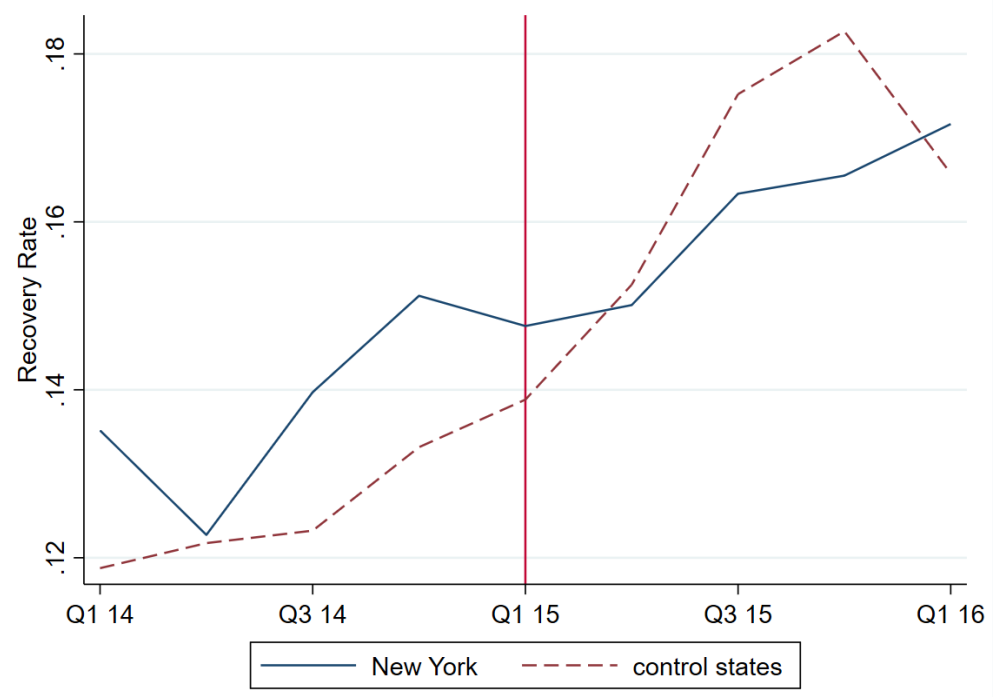

Figure A6: Average recovery rate for Oregon and control states

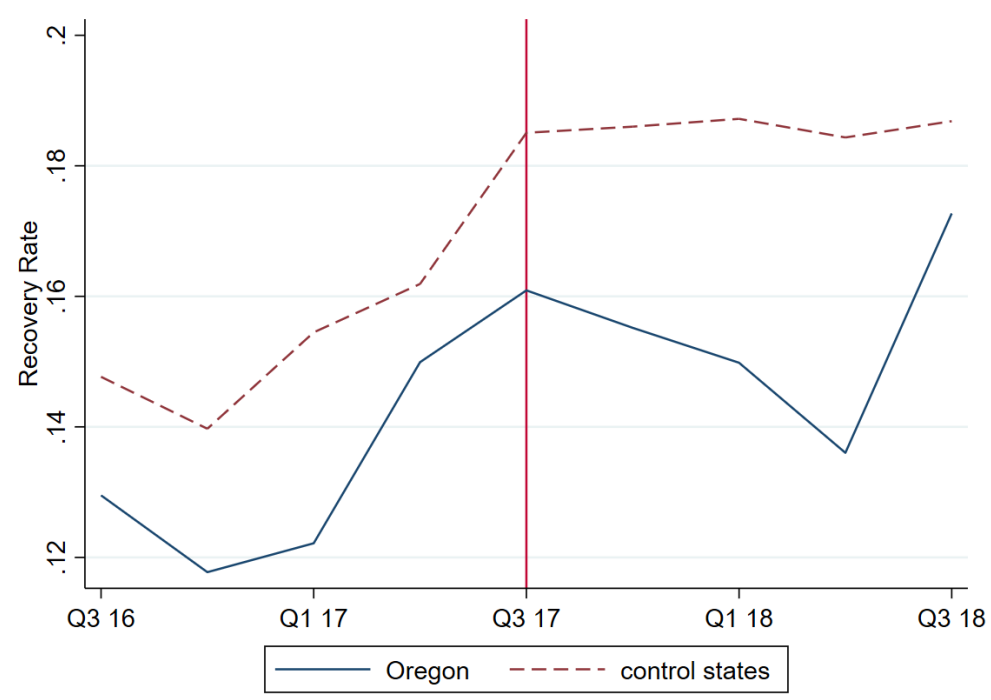


Table A1: Effect of debt collection restrictions on recovery rates: Event Study Estimates

\begin{tabular}{lc}
\hline Dependent Variable & Recovery Rate (\%) \\
Difference-in-Differences Model & \\
Law & -0.421 \\
& $(0.400)$ \\
Event Study Model & -0.152 \\
Quarter - 4 & $(0.650)$ \\
Quarter - 3 & -1.049 \\
& $(0.662)$ \\
Quarter - 2 & 0.683 \\
& $(0.613)$ \\
Quarter - 1 & 0.303 \\
Quarter 0 (omitted) & $(0.488)$ \\
& 0 \\
Quarter 1 & $-0.418^{* *}$ \\
Quarter 2 & $(0.128)$ \\
Quarter 3 & $-1.074^{* * *}$ \\
Quarter 4 & $(0.256)$ \\
& $-0.921^{* *}$ \\
Observations & $(0.353)$ \\
\hline
\end{tabular}

This table reports the event study coefficient estimates of equation $(4-2) .{ }^{* * *} \mathrm{p}<0.01,{ }^{* *} \mathrm{p}<0.05,{ }^{*} \mathrm{p}<0.1$ 


\section{Bibliography}

Barth, J. R., Gotur, P., Manage, N., and Yezer, A. M. J. (1983). The effect of government regulations on personal loan markets: $A$ tobit estimation of a microeconomic model. The Journal of Finance, 38(4):1233-1251.

Bertrand, M., Duflo, E., and Mullainathan, S. (2004). How much should we trust differences-in- differences estimates? Quarterly Journal of Economics, 119(1):249-275.

Braga, B., M. S. R. C. B. T. J. C. C. T. (2019). Local conditions and debt in collections. Journal of Consumer Affairs, 53(4):2058-2085.

Cornaggia, J., Wolfe, B., and Yoo, W. (2018). Crowding out banks: Credit substitution by peer-to-peer lending.

Emekter, R., Tu, Y., Jirasakuldech, B., and Lu, M. (2015). Evaluating credit risk and loan performance in online peer-to-peer (p2p) lending. Applied Economics, 47(1):54-70.

Fedaseyeu, V. (2015). Debt collection agencies and the supply of consumer credit. FRB of Philadelphia Working Paper, (15-23).

Fonseca, J., S. K. Z. B. (2017). Access to credit and financial health: Evaluating the impact of debt collection. FRB of NY Staff Report No. 814.

Gropp, R., Scholz, J. K., and White, M. J. (1997). Personal bankruptcy and credit supply and demand. The Quarterly Journal of Economics, 112(1):217-251.

Jagtiani, J. and Lemieux, C. (2018). The roles of alternative data and machine learning in fintech lending: Evidence from the lendingclub consumer platform. FRB of Philadelphia Working Paper No. 18-15.

Kafer, B. (2018). Peer-to-peer lending - a (financial stability) risk perspective. Review of Economics, 69(1):1-25.

Malekipirbazari, M. and Aksakalli, V. (2015). Risk assessment in social lending via random forests. Expert Systems with Applications.

Maudos, J. (2004). Factors explaining the interest margin in the banking sectors of the european union. Journal of Banking Finance, 28(9):2259-2281. 
Morse, A. (2015). Peer-to-peer crowdfunding: Information and the potential for disruption in consumer lending. Annual Review of Financial Economics, 7(1):463-482.

Pattison, N. (2017). Consumption smoothing and debtor protections. Departmental Working Papers 1703.

Sandler, R. and Romeo, C. J. (2018). The effect of debt collection laws on access to credit. Consumer Financial Protection Bureau Office of Research Working Paper, 2018-01.

Serrano-Cinca, C., Gutiérrez-Nieto, B., and López-Palacios, L. (2015). Determinants of default in $\mathrm{p} 2 \mathrm{p}$ lending. PLOS ONE, 10(10).

Zywicki, T. J. (2015). The law and economics of consumer debt collection and its regulation. Mercatus Working Paper, Mercatus Center at George Mason University. 